\title{
Stednavnenoter fra Ris sogn
}

\section{Af Niels Black Hansen.}

\section{1. "Brundemark".}

I Ảbenrå skrå (udg. af P. G. Thorsen) lyder art. 4: Item fægang nostrum esse debet, prout Rex Woldemarus nobis donauit. in campis septem villarum, scilicet horsthorp, stubeby, athorp, hæsel, gamel opner, loytæ et brunnæmark - - - oversat af V. Marstrand i „Åbenrå“, s. 91:

Videre vor fægang skal være, som kong Valdemar har givet os den, på 7 landsbyers marker, nemlig Hostrup, Stubbæk, Aarup, Hæsel, Gamel Opnør, Løjt og Brundemark - -

Brundemark er altså ifølge teksten en villa, en bebyggelse, sideordnet med 6 andre, og ikke en campus, ikke bymarken til Brunde. Men hvad er det da for en bebyggelse, der er tale om?

Det vilde $\mathrm{i}$ og for sig ligge nær at tænke på torpet Hjarup. Dette navn er, hvis etymologien i "Sønderjyske Stednavne“, IV, 246 og 96 er rigtig, som navn ældre end både Åbenrå borgerries græsningsret og selve byen Åbenrå. Men det ældste belæg for Hjarup er fra slutningen af 15 . århundrede, og navneskifte kunde tænkes her lige så godt som andetsteds, sml. f. eks. Ensted-Stubbæk, Sdj. Stedn. IV, 402. Vi véd imidlertid (Åbenrå byarkiv „die älteren Stadtgrenzen“ -- jfr. Tr. Fink, Udskiftningen etc. s. $59 \mathrm{ff}$.), at det er brundingerne og ikke hjarupperne, borgerne i Åbenrå senere har haft stridigheder med vedrerende den omhandlede græsningsret.

Der kan således næppe være tvivl cm, at det er byen Brunde, der i Åbenrå skrå ka!des Brundemark. Spørgsmålet er her- 
efter dette, om stednavnet Brunde oprindelig har været et navn på - mark. I materialesamlingen i Sdj. Stedn. IV, s. 245 er formen i skråen ældste belæg, men også det eneste med -mark. Brunde ligger nær spredningsområdet for bebyggelsesnavne på -mark (se kortet i Sønderj. Hist. I, s. 292), og tab af - naturligvis tryksvag - endelse vilde være tænkelig. Det vilde dog vistnok være for dristigt på grund af denne ene ganske vist mærkelige og uomtvistelige - navneform i Åbenrå skrå at antage, at Brunde oprindelig har heddet Brundemark. Man bliver betænkelig, når man $\mathrm{f}$. eks. ser, at i Liber censualis episcopi Sleswisencis Arslev by kaldes både Orsleue og Orsleuemark, og her kan det med sikkerhed fastslås, at det drejer sig om en og samme lokalitet, der et sted får et-mark vedhængt, men ellers ikke. Ifølge Sdj. Stedn. Indl. 5 XLV går de fleste af bebyggelsesnavne på -mark da heller næppe længere tilbage i tiden end den ældre middelalder. Eksemplet fra Liber censualis kunde tyde på, at endelsen endnu i 15. århundrede har kunnet tilføjes „vilkårligt“ og for så vidt har været „produktiv“.

\section{Hjarup.}

Hjarup i Ris sogn, nu Rishjarup, kaldes i Øster Logum kirkebog også Sønder Hjarup. Navnefællesskabet mellem de to byer i Ris og Øster Løgum sogne, der i ældre tid naturligvis er blevet kaldt Hjarup slet og ret, ligger for hånden. Nørre Hjarup skilles kun ved en mosestrækning, der på nogle kort benævnes som Hjarup Mose, fra udspringet af en å, der har mange navne, men nu almindeligvis kaldes Gels å, Trap: Hertugd. Slesv. s. 8 betegner sydgrænser for Barvid syssel ved en linje Genner bugt-Jardeå osv. (ikke Jarleå, som der står et par andre steder i samme værk). Iflg. Sønderj. Stedn. optræder Jardeå første gang på Mejers kort hos Danckwerth (Jard fl.), og $\mathrm{Sj}$. Stedn. formcder, at navnet er dannet af Mejer selv som lokal betegnelse for åen ved Hjartbro (Jardebro). Navnet findes dc.g også i sencre kilder, hos Trap som nævnt for åens averste del. Det kendes så sent som 1912 af en indberetter til Sted- 
navneudvalget. Nørre Hjarup kaldes én gang, Rishjarup udelukkende Jarderup i kilderne fra reformationstiden til Danske Atlas. En forbindelse mellem Jardeå og Jarderup kan da i hvert fald vistnok nævnes som en mulighed. Fldre end Åbenrå by vilde torpnavnet jo være også i tilfælde af forleddets appellativiske karakter (se Sj. Stedn. II, 680 under Hjartbro).

\section{3. „Burltoft".}

I Sønd. Stedn. IV, s., 258 står under Ris:

Burltoft (Her?). S. Jb. 1462 (Quellens. VI, 213), Burltoft.

I jordebogens fortegnelse over biskoppens jordegods i Ris sogn hedder det på det anførte sted:

Item 1 stuff inter Kolstorpp Endvidere (har biskoppen) 1 et Zoest et dat annuatim 1 ss. stykke stuf mellem Kolstrup annone et vocatur Burltoft. og Søes. Det giver årlig 1 ørtug korn og hedder Burltoft.

På grænsen til Kolstrup findes på Johs. Mejers bykort af Søes og sognekortet af Ris en mark, der der kaldes henholdsvis Busstofft og Bosstofft. Navnet, som også forekommer i Åbenrå amts jordebog af 1704, er endnu i brug (Danske Folkemål XIV, s. 11). Her er det da åbenbart at „Burltoft" må søges.

Det er nærliggende at antage, at forleddet Burl- $i$ bispens jordebog er en forvanskning. Der er tilsyneladende flere muligheder. Det kan være mandsnavnet Bo eller Boj (Jordebog 1704 Boestofft, Boies Tofft lücke). En anden mulighed er vel det ofte forelkommende appellativiske bod $=$ hytte, skur. Det turde imidlertid også kunne tænkes, at Mejer i Buss- har bevaret noget oprindeligt, da toften har været stuf. Hvis så er, vilde Mejer have overleveret en kirkelig skriftform, ligesom han har Gottsenge for den nærliggende Godskes Eng i Ris (Sønderj. Mdskr. 1946, s. 167). Forskellen er kun den, at det her vilde være den kirkelig form, der måtte anses som den oprindelige.

Beliggenheden taler i hvert fald for, at Burltoft i Sønd. Stedn. IV, s. 258 må udgå og belægget indføjes s. 270 under Bo(d)stoft i Søes. 